\title{
Government Budget Deficits and the Development of the Bond Market in Pakistan: Issues and Challenges
}

\section{Jamshed Y. Uppal*}

\begin{abstract}
This article examines how better discipline can be brought to fiscal policy, first, through enhanced institutional checks and balances, and second, through better market discipline. We examine the political institutions and budgetary processes that can affect fiscal policy in Pakistan. A sound fiscal policy feeds bond market development, while the bond market provides signals in relation to the prudent conduct of fiscal policy. A common dimension in this mutual relationship is the governance environment. The article concludes that instilling fiscal discipline will remain intractable unless approached comprehensively. Long-term solutions must be found in the development of political institutions and improved governance. An active and liquid bond market can play a crucial role in bringing about fiscal discipline. The real challenge lies in summoning the political will and raising public awareness to implement the required measures.
\end{abstract}

Keywords: Budget Deficit, Fiscal Policy, Bond Market, Pakistan.

JEL Classification: E62, H61, H62.

\section{Introduction}

Pakistan initiated financial sector reforms in the early 1990s and took regulatory and structural measures to liberalize the economy and develop financial markets and institutions. One rationale for these reforms was to institute market discipline in the monetary and fiscal management of the economy. Following the economic liberalization policies, Pakistan's financial sector has experienced remarkable growth and structural development. However, it is debatable whether the financial markets have contributed meaningfully to the execution of sounder macroeconomic management; in particular, control of fiscal deficits remains a challenge.

\footnotetext{
* Associate Professor of Finance, Department of Business and Economics, Catholic University of America, Washington, DC.
} 
Besides being an emerging market, Pakistan is also an emerging democracy, or rather a re-emerging democracy whose democratic process has been interrupted a few times. The newly re-established democratic environment poses both a challenge and opportunity to review governmental processes and institutions that would be not only more in tune with a democratic spirit, but also more aligned with public interest. Democratic processes and institutions can provide the right set of checks and balances, not only political, but also in economic management. One important area in which institutions urgently need to be reengineered is the formulation and conduct of fiscal policy.

This article examines how better discipline can be brought to fiscal policy, first, through enhanced institutional checks and balances, and second, through better market discipline. We examine the political institutions and budgetary processes that can affect fiscal policy in the context of Pakistan. We then address the linkages between government fiscal deficits and financial markets, in particular the bond market. Fiscal policy feeds bond market development, while the bond market provides signals in relation to the prudent conduct of fiscal policy. A common dimension in this mutual relationship is the governance environment; an appropriate regulatory and legal environment not only fosters bond market development, but is also conducive to the conduct of sound fiscal policy. These dynamic relations are depicted schematically in Figure 1.

Figure 1: Fiscal Policy, Environment, and Financial Markets

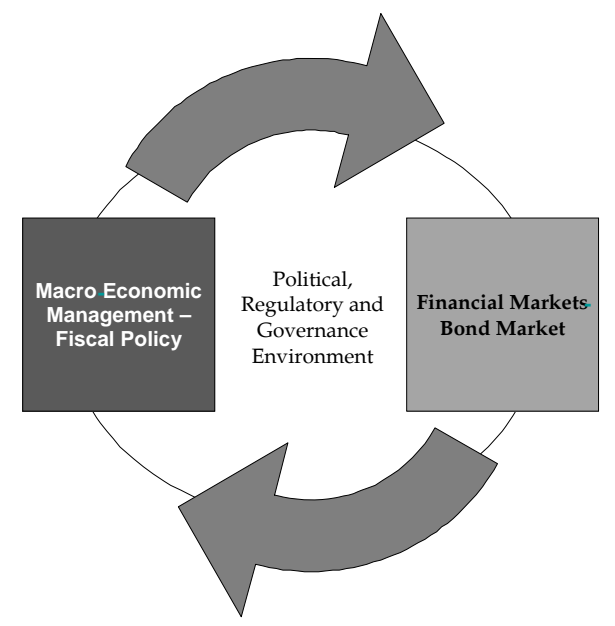

The article is organized as follows. The introduction is followed by a brief background of Pakistan's fiscal position, and explains how the government deficit is financed. Section III surveys the theoretical issues that 
arise in the political economics of fiscal policy, and evaluates Pakistan's governance and regulatory environment in light of these theories and empirical evidence from other countries. Section IV discusses the linkages between fiscal deficits and the bond market, surveying the theoretical models and empirical evidence and their relevance to developing countries. Section V outlines the development of the bond market in Pakistan and the challenges it faces in assuming a constructive role in shaping prudent fiscal policies. Section VI summarizes the issues raised, synthesizes the arguments and empirical evidence, and develops policy recommendations.

\section{Pakistan's Fiscal Woes}

That Pakistan's current fiscal position is in dire straits is acknowledged in all quarters. The State Bank of Pakistan's (2010) most recent Financial Stability Review (FSR) notes that, "when viewed in a historical perspective, it comes to light that Pakistan's economy has faced, since inception, perennial and persistent fiscal deficits, varying from as low as 2.9 percent to as high as 12.2 percent of GDP [gross domestic product]" (Figure 2). The FSR explains this as emanating "largely from insufficient revenue generation due to lack of appropriate governance measures which tend to encourage tax evasion and a substantially large and thriving undocumented or parallel economy functioning alongside." Rigidity in expenditures along with "poor fiscal discipline" has been aggravated by weak cash management, in particular by a lack of cash flow forecasting. As a consequence of the fiscal deficits, and given the unpredictability of the financing requirements and availability, the government finds it most feasible to borrow from the banking system, including from the State Bank of Pakistan.

Figure 2: Fiscal Balances as a Percentage of GDP

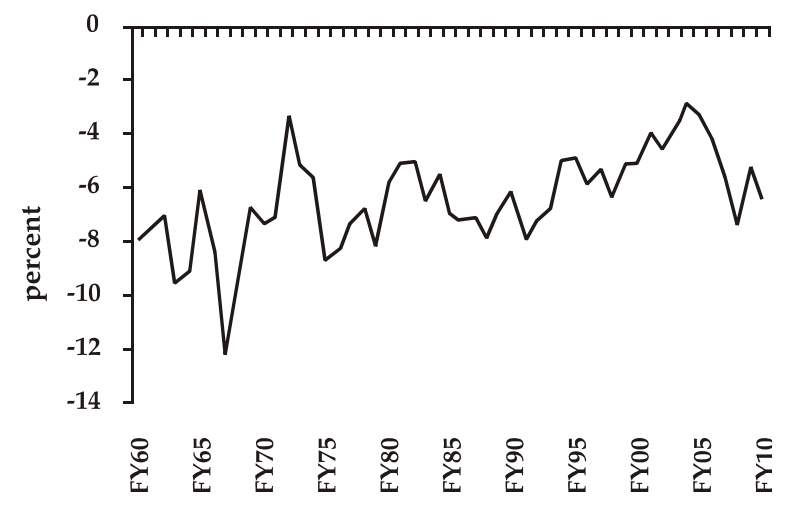

Source: Ministry of Finance

$\mathrm{FY}=$ fiscal year, $\mathrm{GDP}=$ gross domestic product. 
The FSR provides various reasons for the economy's historically weak fiscal performance: (i) sluggish revenue growth, (ii) a narrow tax base and tax incidence that is skewed toward the industrial sector and a small number of return filers, (iii) wide-ranging exemptions and concessions, and tax evasion, and (4) reliance on indirect taxes (State Bank of Pakistan, 2010). On the other hand, the expenditure side is encumbered by defense and interest expenses not amenable to cuts. This is compounded by a fragmented cash management and budgetary system that does not generate reliable cash forecasts and effective control.

The overall deficits and financing sources are summarized in Table 1. Persistent budgetary deficits have pushed the total debt and liability stock to 69.5 percent of GDP, with the ratio increasing by 9 percent in just the last three years. The fiscal year (FY) 2008 saw a large increase in the percentage of the deficit being financed by internal sources, from 61.0 to 80.5 percent, of which the central bank was the main source. This is explained by lower-than-targeted external loan inflows and constrained access to international markets. The increased reliance on internal borrowing continued through FY2010 with heavier contributions from "nonbank" sources, which include prize bonds, treasury bills, and national saving scheme. The bulk of this was raised through the second and third sources in FY2010. The country appears to face constraints to external borrowing as well as long-term domestic borrowing.

Table 1: Overall Deficits and Sources of Finance

\begin{tabular}{lrrrrrr}
\hline Deficit/Financing Sources & FY2005 & FY2006 & FY2007 & FY2008 & FY2009 & FY2010 \\
\hline Overall deficit (Rs billion) & $(217.0)$ & $(325.3)$ & $(377.5)$ & $(777.2)$ & $(680.4)$ & $(929.1)$ \\
$\quad$ As a percentage of GDP & -3.3 & -4.3 & -4.4 & -7.6 & -5.3 & -6.3 \\
Financing of deficit & & & & & & \\
External sources & 55.5 & 45.8 & 39.0 & 19.5 & 22.0 & 20.3 \\
Internal sources & 44.5 & 54.2 & 61.0 & 80.5 & 77.9 & 79.7 \\
Central bank & 70.5 & 40.7 & -15.5 & 87.1 & 16.8 & 4.5 \\
Scheduled banks & -42.7 & -18.9 & 42.6 & -20.2 & 28.0 & 28.3 \\
Nonbank sources & 3.7 & 2.5 & 15.1 & 13.4 & 32.9 & 46.9 \\
Privatization proceeds & 13.0 & 29.9 & 18.9 & 0.2 & 0.2 & 0.0 \\
Total & $\mathbf{1 0 0 . 0}$ & $\mathbf{1 0 0 . 0}$ & $\mathbf{1 0 0 . 0}$ & $\mathbf{1 0 0 . 0}$ & $\mathbf{9 9 . 9}$ & $\mathbf{1 0 0 . 0}$ \\
\hline
\end{tabular}

FY = fiscal year, GDP = gross domestic product.

Source: State Bank of Pakistan. (2010). Government borrowing from the banking system: Implications for monetary and financial stability. Financial Stability Review, 200910. Karachi, Pakistan. 
In addition to government borrowing for budgetary support, government borrowing from the banking system includes (i) the provincial governments' borrowing in the form of "ways and means" advances, and (ii) borrowing to meet the quasi-fiscal deficit incurred by public sector enterprises for commodity operations and other subsidies. There has been substantial growth in the government's total borrowing over the last six years (Figure 3). A major increase in borrowing from the banking system occurred in FY2008 (64.5 percent) with borrowing from the State Bank of Pakistan increasing by 200 percent. In FY2010, however, borrowing from scheduled banks registered a significant jump of 55.3 percent.

Figure 3: Share in Net Government Borrowing from the Banking System

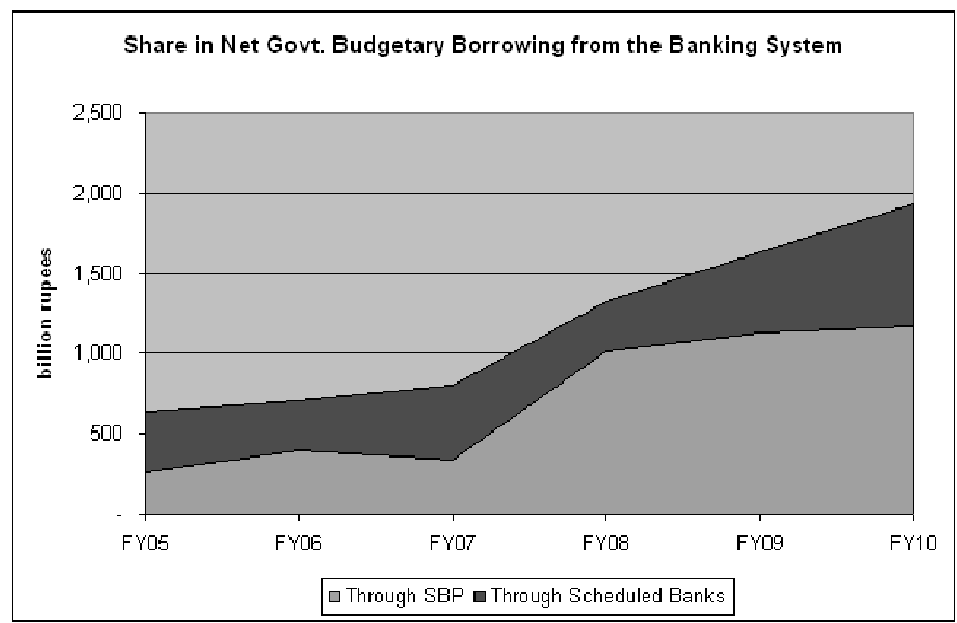

Source: State Bank of Pakistan. (2010). Government borrowing from the banking system: Implications for monetary and financial stability. Financial Stability Review, 200910. Karachi, Pakistan.

The adverse implications of excessive borrowing from the banking system are well recognized. In addition to its negative impact on inflation, economic growth, and monetary stability, the FSR notes that banks have started to charge a premium on loans to the public sector, despite their being risk-free. The continued pattern of borrowing is likely to distort banks' incentives for commercial lending and the process of financial deepening.

\section{Country Policy and Institutional Assessment}

One way of evaluating the country's fiscal and debt policy is with reference to the country policy and institutional assessment (CPIA) ratings developed by the World Bank (2005), which are used to guide the 
allocation of International Development Association lending resources. CPIA ratings assess the quality of a country's present policy and institutional framework; here, "quality" refers to how conducive that framework is to fostering poverty reduction, sustainable growth, and the effective use of development assistance. The CPIA consists of a set of criteria representing the different policy and institutional dimensions of an effective poverty reduction and growth strategy.

Figures 4 and 5 show the CPIA fiscal policy and debt policy ratings for a select group of countries for the period 2005-09. Of the six countries compared, only Pakistan's fiscal policy rating deteriorated during this period. The other five countries improved or maintained their ratings. Similarly, only Pakistan's CPIA debt policy rating deteriorated during this time, while that of the rest of the group was either maintained or improved.

Figure 4: CPIA Fiscal Policy Ratings

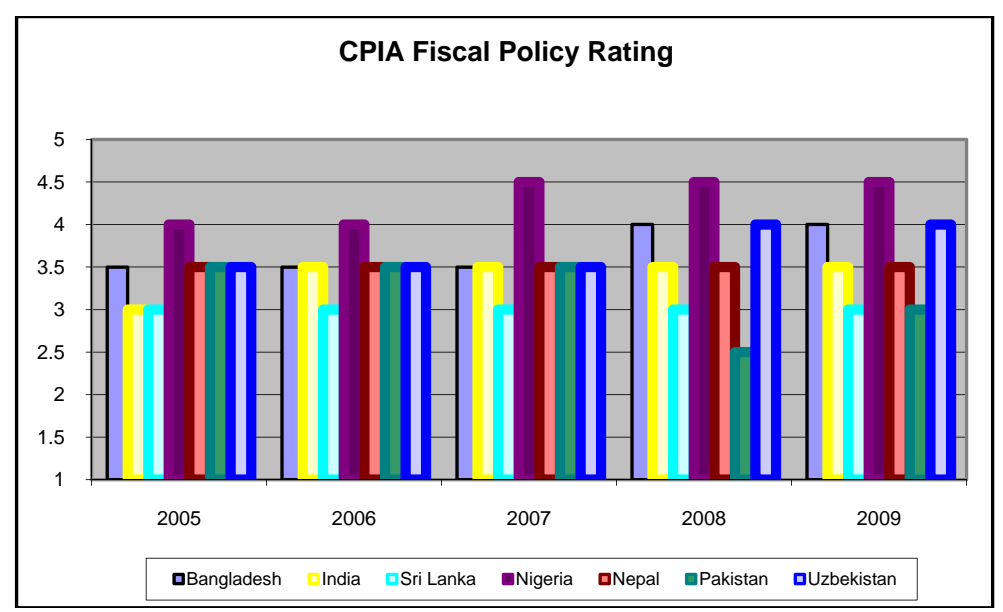

Source: World Bank. (2005). Country policy and institutional assessments: Assessment questionnaire. In Operations policy and country services. Washington, DC: Author. 
Figure 5: CPIA Debt Policy Ratings

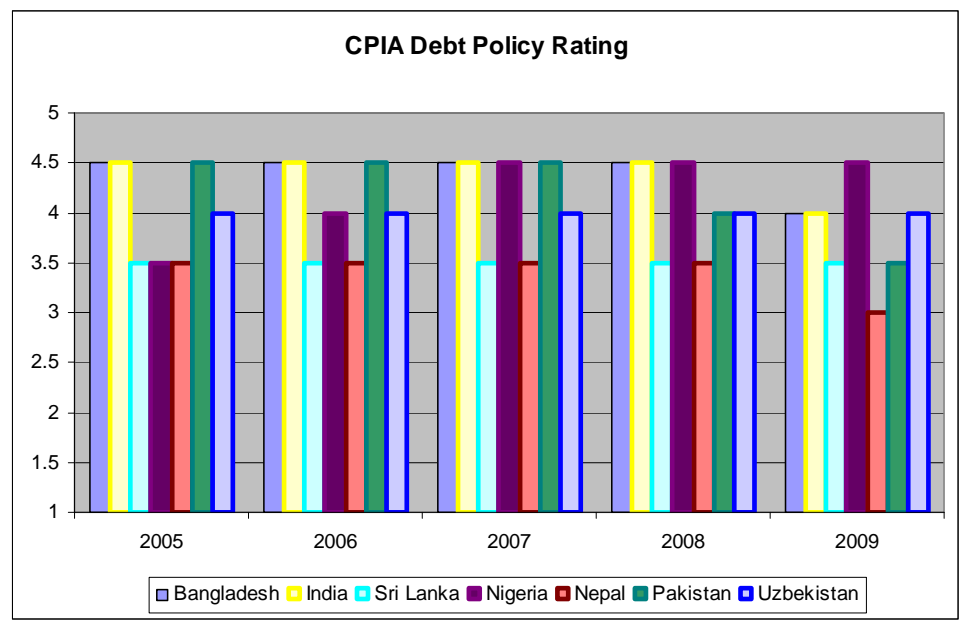

Source: World Bank. (2005). Country policy and institutional assessments: Assessment questionnaire. In Operations policy and country services. Washington, DC: Author.

More direct comparisons of Pakistan's fiscal deficits with a number of cohort countries are also unfavorable. Figure 6 depicts fiscal deficits (as a percentage of GDP) for India and Pakistan and shows that, over the 20-year period, India's budget deficits were relatively more contained, and improved dramatically over the last six years.

\section{Figure 6: Budget Surpluses/Deficits as a Percentage of GDP}

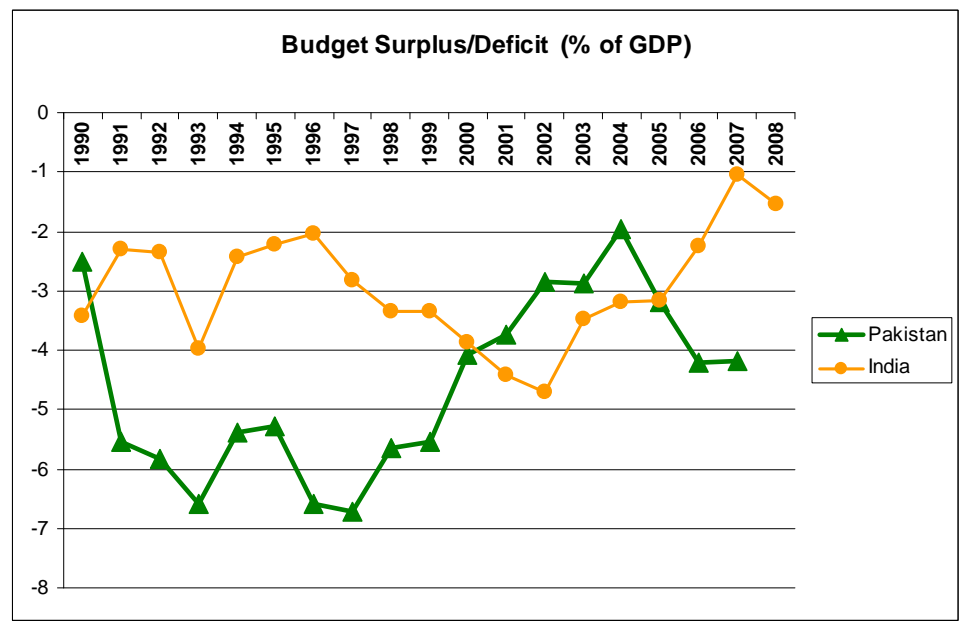

$\mathrm{GDP}=$ gross domestic product.

Source: World Bank. (2005). Country policy and institutional assessments: Assessment questionnaire. In Operations policy and country services. Washington, DC: Author. 
The reasons underlying these persistent fiscal deficits are extensively discussed in the economic literature on Pakistan. Here, we focus on some of the characteristics of the institutional and political environment that generate incentives to reinforce budgetary indiscipline and constrain adjustments and remedies.

\section{The Political Economy of Fiscal Policy}

The political economy literature explains why suboptimally high public deficits may be an outcome of the political process. Alesina and Perotti (1995) provide a critical survey of the literature on politicoinstitutional determinants of the government budget. Eslava (2006) surveys more recent literature on the political economy of fiscal policy, in particular the accumulation of government debt. We draw on both these works to focus on the main themes in the theoretical literature and empirical evidence on the subject.

Alesina and Perotti (1995) start by rejecting the "tax smoothing" model of the government budget, which assumes the government to be a "benevolent social planner" that maximizes the utility of the representative agent. Given the concavity of the utility function and the inter-temporal budget constraint, the policy prescribes a constant tax rate. Budget deficits and surpluses are used as a buffer; deficits occur when spending is temporarily high, and surpluses when it is low. This implies that budget deficits should be observed during "wars" and recessions. Alesina and Perotti note that the model does not explain the experience of Organisation for Economic Co-operation and Development (OECD) economies during 1960-94, and then discuss politico-institutional approaches organized into six models based on

1. opportunistic policymakers and naive voters with "fiscal illusion,"

2. intergenerational redistributions,

3. the use of debt as a strategic variable linking the current government with the next one,

4. the political dynamics of coalition governments,

5. geographically dispersed interests, and

6. the effects of budgetary institutions on fiscal discipline. 


\section{Political Opportunism}

The "fiscal illusion" argument is that voters do not understand the government's inter-temporal budget constraint, and overestimate the benefits of current expenditures while underestimating the future tax burden. Politicians behave opportunistically by raising government spending beyond taxes to please their voters. A related phenomenon is the observed political business cycle-that politicians follow expansionary policies in election years. Supporting this argument is the tendency of Keynesian stabilization policies to be followed asymmetrically: politicians are more inclined to run deficits in recessions, but not as inclined to run surpluses in post-recession periods. These models imply that it is difficult for the electorate to understand the complexity of the government budget, and that the electorate makes errors with a systematic bias. However, there might be systematic differences across countries in the degree of "illusion," political opportunism, or complexity and noise in the tax structure, especially considering the degrees of development in various countries.

The more recent literature has attempted to explain why even perfectly rational voters may be led to vote for opportunistic politicians who incur deficit spending. Rogoff (1990) and Rogoff and Sibert (1988) argue that voters have only imperfect information about the competence level of each politician. Politicians who provide more government programs are inferred to be more competent and thus attract votes. This in turn leads politicians to expand public spending and incur larger deficits. In this line of explanation, a key link is the inability of voters (or some voters) to observe all the details of the budget and form a view of the incumbent's competence. How transparent the budget is depends on factors such as the government's accounting practices, media development, and the sophistication of voters, which varies across countries.

Alt and Lassen (2006) provide evidence from 19 OECD countries during the 1990s showing that fiscal transparency is systematically related to the levels of deficit and debt. Alesina and Perotti (1999) and Stein, Talvi, and Grisanti (1998) use an index of budget institutions that also captures transparency to find that better budget institutions were related to lower deficits in a sample of 20 Latin American countries during the 1980s and early 1990s. Similar evidence is provided by von Hagen (1992) for eight European countries. 
Election-related increases in spending and deficits are documented, particularly for developing countries (Schuknecht, 1994; Shi \& Svensson, 2006). Brender and Drazen (2005a) note that these findings reflect the experience of new democracies in the first few years after their transition to democratic regimes. They suggest that election cycle-related deficits occur in countries where voters and the media have not yet developed the ability to efficiently monitor fiscal policy. Shi and Svensson (2006) attribute it to the share of voters who are well informed. They also find that higher levels of corruption imply larger deficit increases in election years.

Contrary to the traditional view that voters penalize fiscal adjustments, recent empirical findings suggest that voters' reaction to fiscal conservatism or otherwise depends on the composition of government spending, such as the share of development and infrastructure project expenditure. Voters' opposition to deficits appears to be related to their ability to monitor fiscal choices. Brender and Drazen (2005b) find that deficits over the previous three years reduce an incumbent's re-election chances, but only in established democracies.

\section{Intergenerational Models}

The intergenerational models suggest that fiscal deficits are a way to effect intergenerational redistributions. However, in the presence of intergenerational altruism, Ricardian equivalence comes into play (Barro, 1979), implying that the choice of how to finance a given level of spending is irrelevant as changes in public debt are compensated for by changes in private bequests. On the other hand, in a variety of circumstances, Ricardian equivalence does not hold, and since only the current generation votes, a selfish generation could shift the burden of taxation to the future. As long as one group of agents (the altruistic) is indifferent to any debt policy, the other group (the selfish) will favor public debt; the social choice is likely to lead to debt.

Alesina and Perotti (1995), however, do not find the intergenerational approach convincing in the face of the historical public debt patterns and trends that emerged in the OECD countries. Tabellini (1991) explains that intergenerational redistributions interplay with intragenerational redistribution, and shows that, as long as there is an asymmetric preference for default, the political equilibrium implies issuing debt, which is then honored. 


\section{Public Debt as a Strategic Variable}

Competing political parties can use debt strategically to bind future governments. The party in power can affect the future state of the world inherited by the competing political party through fiscal choices (Alesina \& Tabellini, 1990). A fiscal deficit that is financed by raising debt commits future tax revenues to debt servicing, and reduces future governments' spending. Such strategic interaction leads to government borrowing, which is predicted to be larger, the greater the extent of polarization among political parties over the composition of government spending and the greater the likelihood of a change in government. The models also imply that high-debt countries should have more highly polarized political parties and electorates with strong extremist groups. These models are supported by the experience of the OECD countries post-1973 when there was less political and economic stability, and by preliminary evidence based on an index of political stability for OECD countries provided by Alesina (1989). However, other studies have not consistently favored these models. The lack of clear evidence has been attributed to the use of samples consisting of countries with widely different political, legal, and economic environments, and the difficulties in identifying the source of heterogeneity of preferences in the electorate.

\section{Distributional Conflicts}

In the distributional conflicts and wars of attrition models, fiscal deficits are the result of (i) strategic conflicts between political parties or social groups that have an influence on policy decisions at the same time, and (ii) the polarization of parties that are members of the same coalition government. Following a permanent shock that disturbs the government budget, causing a deficit to emerge and debt to accumulate, the distributional struggle among social groups delays the adoption of an efficient policy to balance the budget. Stabilization costs can be categorized in two ways: (i) the economic costs of pre-stabilization distortions, and (ii) the political costs of preventing the other group from imposing an undesirable fiscal plan. The more unequal the distribution of stabilization costs, the higher the benefits of waiting, and the longer the time for resolution. Spolaore (1993) shows that a coalition government delays adjustment while a single-party government reacts too much, relative to the optimal. Hence, the accumulation of public debt can be attributed in part to the fragmentation of governments and degree of political cohesion. 
The heterogeneity of interests across groups of voters is hypothesized to lead to pervasive deficits; the budget size and deficit is predicted to increase with the number of districts represented in the government, and is termed government "fragmentation." Such "common-pool problems" may explain the pro-cyclicality of fiscal policy in less developed economies where the additional fiscal resources available during booms generate a more intense fight for the common pool of resources-the "voracity effect" (Talvi \& Végh, 1996, 2005; Tomell \& Lane, 1998).

The distributional conflict models may be more relevant to developing economies (these also exhibit pro-cyclical fiscal policy) for two reasons. First, there is greater macroeconomic volatility and economic booms generate large but short-lived extra revenues, providing greater incentive to fight for a greater share. Second, these countries are characterized by less budgetary transparency and higher levels of corruption. Alesina and Tabellini (2005) show that, in a sample of 87 countries between 1960 and 1999, pro-cyclicality and corruption were indeed positively correlated, but only for democracies. The empirical studies meant to test these hypotheses are, however, hamstrung by the difficulties in differentiating between the related concepts of fragmentation and polarization. However, the studies generally confirm that greater political cohesion and stability accompanies better fiscal discipline. There is less support for a systematic relationship between leftwing or right-wing parties and larger debt accumulation.

\section{Geographically Dispersed Interests}

A number of models focus on the geographic base of members of the legislature as leading to "excessive" spending. In the Weingast, Shepsle, and Johnsen (1981) model, representatives with a geographically based constituency overestimate the benefits of public projects in their districts relative to the financing costs, which are distributed nationwide and are not internalized. The aggregate effect is an oversupply of geographically based public projects (so called pork barrel projects). Such models underscore the interplay of the geographical distribution of costs, benefits, and decision power affecting the aggregate budget. In particular, these issues are analogous to issues of fiscal federalism.

In Pakistan, local spending decisions are made at the provincial level, but financed by transfers from the federal government, which raises tax revenues. Here, the provincial and the local authorities may not fully 
internalize the effects of their spending decisions over the overall budget for the same reasons that geographically elected representatives do not. It is obvious that the incentives for local authorities would be different if they were responsible for both taxing and spending decisions.

\section{Budgetary Institutions}

The rules and regulations according to which budgets are drafted, approved, and implemented can potentially impact fiscal deficits and debts. Their impact is significant since budget institutions are more difficult to change and influence the final vote and implementation of the budget. Budgetary procedural rules may specify who holds agendasetting power and what types of amendments are admissible on the legislature floor. It is suggested that rules that limit universalism and reciprocity lead to fiscal restraint. "Universalism" refers to a budget that includes "something for everybody." "Reciprocity" means an understanding among legislators not to oppose another representative's proposal in exchange for the same favor.

As in the case of the models presented in the previous section, research in this area has an American focus. American states have varied budgetary institutions. In particular, some states have "hard" balanced budget rules, others have "soft" balanced budget rules, while a few have no such rules. Von Hagen (1991) provides evidence that budget rules have some effect on the level and composition of state debts. Research by Alt and Lowry (1994) and Poterba (1994) shows that American states with harder balanced budget rules react more promptly and more energetically to negative revenue shocks or positive spending shocks. Von Hagen (1992) studies the budgetary institutions of the 12 European Economic Community member countries, and finds support for the hypothesis that "budget procedures lead to greater fiscal discipline if they give strong prerogative to the prime minister or the finance minister; limit universalism, reciprocity and parliamentary amendments; and facilitate strict execution of the budget law." Von Hagen has constructed indices to capture the relevant characteristics of budgetary institutions. These are: (i) the strength of the prime minister's (or finance minister's) position, (ii) the limits to parliamentary amendments, (iii) the type of parliamentary votes, (iv) the timing of parliamentary votes, (v) the degree of transparency of the budget, and (vi) the amount of flexibility in the implementation process. 
In Pakistan, the passage of the Fiscal Responsibility and Debt Limitation Law has been in the spirit of instituting budget rules, which could help attain both fiscal discipline and transparency. However, the impact of the law has, so far, been limited.

The Role of the Courts

Like any other law, the budget is subject to judicial review, and the judiciary can thus be a potentially important player in the determination of fiscal policy ${ }^{1}$ Specific groups affected by fiscal adjustments have incentives to organize and take legal action against these measures. On the other hand, benefits from such adjustments are widespread throughout society and it is hard to organize efforts to defend it. This asymmetry in collective action tends to block necessary fiscal adjustment through legal challenges raised by organized groups. Using a sample of 23 Latin American and Caribbean countries for the period 1996-2003, Eslava (2006) provides evidence that "the degree of involvement of the courts in the design of fiscal policy is a key determinant of the level of deficit." This is consistent with situations in which courts may rule that spending increases are necessary to guarantee a series of constitutional rights.

\section{Corruption and Public Finance}

In recent years, there has been growing recognition that the level of corruption exacerbates the problems of fiscal management. International institutions have emphasized that controlling corruption is key to sound governance and economic management. Corruption is likely to be a major factor in poor tax collection. ${ }^{2}$ In addition to corruption in the bureaucracy, political corruption by high-ranking state officials and their cronies may increase the incidence of misuse of administrative powers to pursue rent seeking and corrupt practices. Laws and regulation could be written to the advantage of powerful lobbies.

Corruption can affect public expenditure in several different ways due to a lack of transparency and of effective institutional controls. Large public projects are ripe ground for corrupt and rent-seeking officials with discretionary powers in many critical decisions, with the result that public

\footnotetext{
${ }^{1}$ The Inter-American Development Bank (2005) documents the role the judiciary plays in determining economic policy.

${ }^{2}$ Tanzi (1999) identifies several factors that increase the scope of corruption on the revenue and expenditure side of public finances.
} 
spending can become distorted, both in size and composition. Many public projects across the world have been carried out specifically to benefit some individuals or political groups. In order to combat corruption, countries are forced to develop complex and costly procedures, which, while reducing corruption, increase the cost of administration and projects, and of the procurement of goods and services. Corruption negatively impacts tax revenue, public spending, and fiscal deficit, and thus leads to poor economic performance. Tanzi (1999) presents a short summary of empirical evidence on the impact of corruption. In particular, one of these studies shows that a one-point increase in the corruption index reduces tax revenue collected by 2.7 percent of GDP.

Corruption not only affects the amount of total domestic investment, it also adversely impacts the amount of foreign direct investment, the size of public investment, and the quality of investment decisions. Interestingly, the unpredictability of corruption has a further negative impact on foreign direct investment. High levels of corruption are also associated with (i) low operation and maintenance expenditure, and (ii) poor-quality infrastructure. Corruption distorts the composition of public expenditure with long-term consequences for economic growth: e.g., countries that are more corrupt spend less on education and health.

A number of policy guidelines are available for countries seeking to reduce corruption (see, for example, Martinez-Vazquez, Arze, \& Boex, 2006; Schaeffer, 2002). Tanzi (1999) emphasizes that, to improve governance and reduce corruption, countries need to modify and reduce the state's role in the economy. It is "important to modify the role of the state by reducing its reliance on regulations, authorizations, quasi-fiscal activities, and other activities and tools that lend themselves to abuse by public officials. It is also important to make the state's actions more transparent." Increasing fiscal transparency can help reduce corruption and improve governance. A relevant structured approach would be to adopt and apply the principles embodied in the Code of Good Practices on Fiscal Transparency developed by the International Monetary Fund (IMF) in 1998.

\section{Policy Implications for Pakistan}

The literature on the political economy of fiscal policy has important implications for institutional reforms. If fiscal policy is a product of politico-institutional characteristics, then one must address related issues at an institutional level. Many countries, like Pakistan, are struggling with hard fiscal adjustments and reforms. Many developing 
countries are building democratic institutions and budgetary institutions that deal with legislative processes as well as more general institutional reforms, such as changes in electoral laws.

The relevance of the various theories bearing on fiscal policy in the context of Pakistan is summarized in Table 2. We can also speculate on the tractability of these factors to indicate some priorities concerning the focus of public effort. It seems that, as an emerging democracy, the political scene is still rife with political opportunism without a strong tradition of accountability either through the polls or the judicial system. The electorate might also be naïve, and entertain some degree of fiscal illusion. Improving this dimension would entail maturing as a democracy. There is not much discussion of intergenerational issues, nor are there many programs with implied intergenerational transfers. We have experienced some budgetary battles where various interest groups have sought to increase their share of common resources and minimize their tax burden. Areas with great promise for improvement seem to be control of corruption and the development of budgetary institutions that support budgetary discipline, such as greater fiscal transparency, an improved system of financial management and control, and audits. 


\section{Table 2: Political Dimensions of Fiscal Environment Plausibility, Tractability, and Policy Direction for Pakistan}

\begin{tabular}{|c|c|c|c|}
\hline $\begin{array}{l}\text { Political and } \\
\text { Governance Factors in } \\
\text { Fiscal Indiscipline }\end{array}$ & $\begin{array}{c}\text { Plausibility } \\
\text { and } \\
\text { Relevance }\end{array}$ & $\begin{array}{l}\text { Tract- } \\
\text { ability }\end{array}$ & $\begin{array}{l}\text { Indicated Policy } \\
\text { Directions }\end{array}$ \\
\hline Political opportunism & $\star \star \star$ & $\star$ & $\begin{array}{l}\text { Introduce transparency in } \\
\text { budgets and government } \\
\text { accounting, media } \\
\text { development, voter awareness }\end{array}$ \\
\hline $\begin{array}{l}\text { Intergenerational } \\
\text { conflicts }\end{array}$ & - & - & $\begin{array}{l}\text { Promote intergenerational } \\
\text { altruism, voter awareness }\end{array}$ \\
\hline $\begin{array}{l}\text { Public debt as a } \\
\text { strategic variable }\end{array}$ & $\star$ & $\star$ & $\begin{array}{l}\text { Lessen political polarization } \\
\text { for political and economic } \\
\text { stability }\end{array}$ \\
\hline Distributional conflicts & $\star \star$ & $\star$ & $\begin{array}{l}\text { Lessen fragmentation of } \\
\text { government, increase political } \\
\text { cohesion, macroeconomic } \\
\text { stability }\end{array}$ \\
\hline $\begin{array}{l}\text { Geographically } \\
\text { dispersed interests }\end{array}$ & $\star \star$ & $\star \star$ & $\begin{array}{l}\text { Internalize cost of fiscal } \\
\text { indiscipline across } \\
\text { geographically dispersed } \\
\text { government units }\end{array}$ \\
\hline Budgetary institutions & $\star \star \star$ & $\star \star$ & $\begin{array}{l}\text { Adopt balanced budget rules } \\
\text { and institutions that limit } \\
\text { universalism and reciprocity }\end{array}$ \\
\hline $\begin{array}{l}\text { Corruption and public } \\
\text { finance }\end{array}$ & $\star \star \star$ & $\star \star$ & $\begin{array}{l}\text { Improve rule of law, reduce } \\
\text { state's discretionary role, } \\
\text { induce transparency in state's } \\
\text { actions }\end{array}$ \\
\hline The role of the courts & - & - & $\begin{array}{l}\text { Reduce scope of judicial } \\
\text { review of budgets, and } \\
\text { asymmetry in judicial } \\
\text { advocacy by organized } \\
\text { groups }\end{array}$ \\
\hline
\end{tabular}

\section{Governance Environment in Pakistan}

In order to assess Pakistan's governance environment in comparison with other countries, we use a set of aggregate governance indicators developed by the World Bank (see Kaufmann, Kraay, \& Mastruzzi, 2004, for a detailed discussion). These indicators are: 
1. Voice and accountability: The extent to which a country's citizens are able to participate in selecting their government, as well as freedom of expression, freedom of association, and a free media.

2. Political stability and absence of violence: Perceptions of the likelihood that the government will be destabilized or overthrown by unconstitutional or violent means, including political violence and terrorism.

3. Government effectiveness: The quality of public services, the quality of the civil service and the degree of its independence from political pressures, the quality of policy formulation and implementation, and the credibility of the government's commitment to such policies.

4. Regulatory quality: The government's ability to formulate and implement sound policies and regulations that permit and promote private sector development.

5. Rule of law: The extent to which agents have confidence in and abide by the rules of society, and in particular the quality of contract enforcement, the police, and the courts, as well as the likelihood of crime and violence.

6. Control of corruption: The extent to which public power is exercised for private gain, including both petty and grand forms of corruption, as well as "capture" of the state by elites and private interests.

The country's rating in terms of these governance indicators is depicted in Figures 7 to 12 in comparison with a selected group of countries for the period 1999-2010. As seen in the figures, Pakistan's governance environment ranks among the bottom of the group. None of the six indicators seem to have improved much over the 20-year period. The indicators for "rule of law" and "political stability and absence of violence" appear to have continuously deteriorated. "Government effectiveness" and "control of corruption" show periods of ups and downs with a somewhat downward trend in the more recent period. "Voice and accountability" and "regulatory quality," however, indicate slight improvements, although compared to other countries there could have been more improvement. 
Figure 7: Comparisons of Governance Indicators (Voice and Accountability)

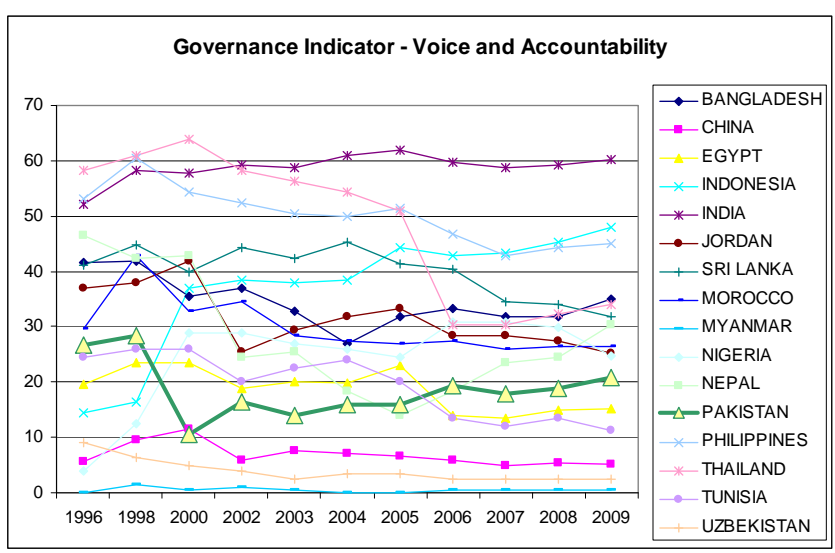

Source: Kaufmann, D., Kraay, A., \& Mastruzzi, M. (2004).

\section{Figure 8: Comparisons of Governance Indicators (Government Effectiveness)}

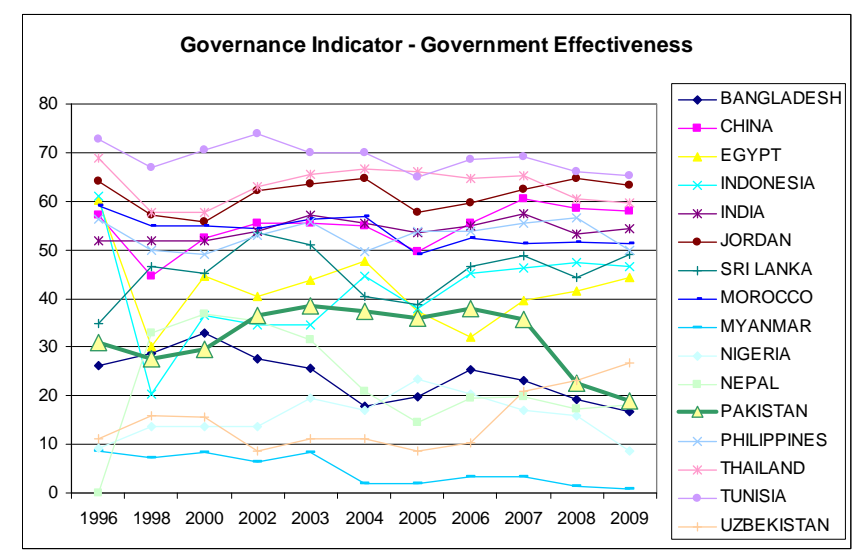

Source: Kaufmann, D., Kraay, A., \& Mastruzzi, M. (2004). 


\section{Figure 9: Comparisons of Governance Indicators (Political Stability)}

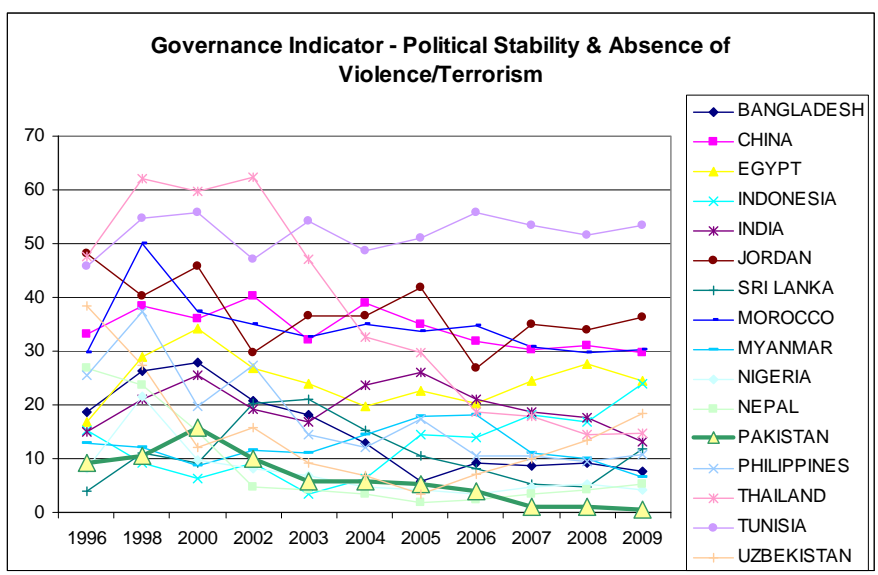

Source: Kaufmann, D., Kraay, A., \& Mastruzzi, M. (2004).

Figure 10: Comparisons of Governance Indicators (Rule of Law)

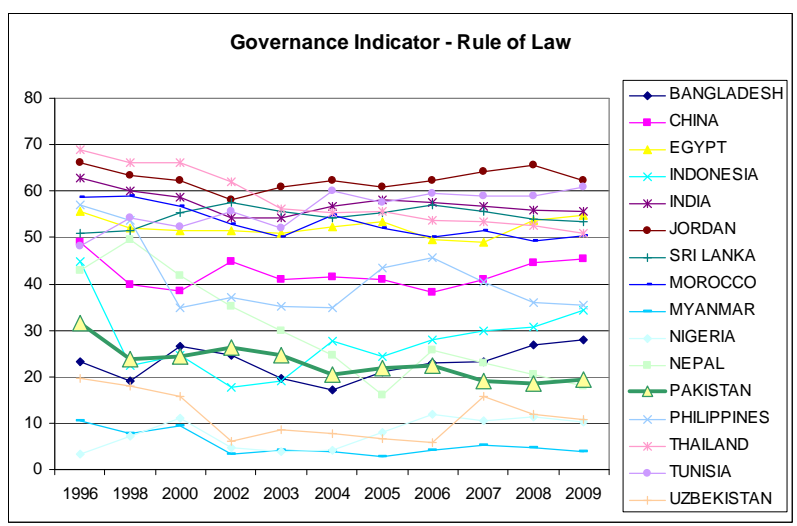

Source: Kaufmann, D., Kraay, A., \& Mastruzzi, M. (2004). 
Figure 11: Comparisons of Governance Indicators (Regulatory Quality)

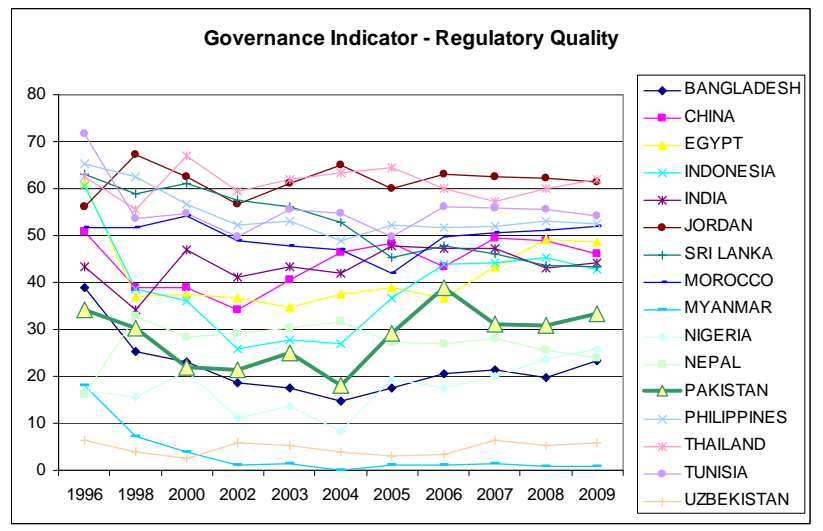

Source: Kaufmann, D., Kraay, A., \& Mastruzzi, M. (2004).

Figure 12: Comparisons of Governance Indicators (Control of Corruption)

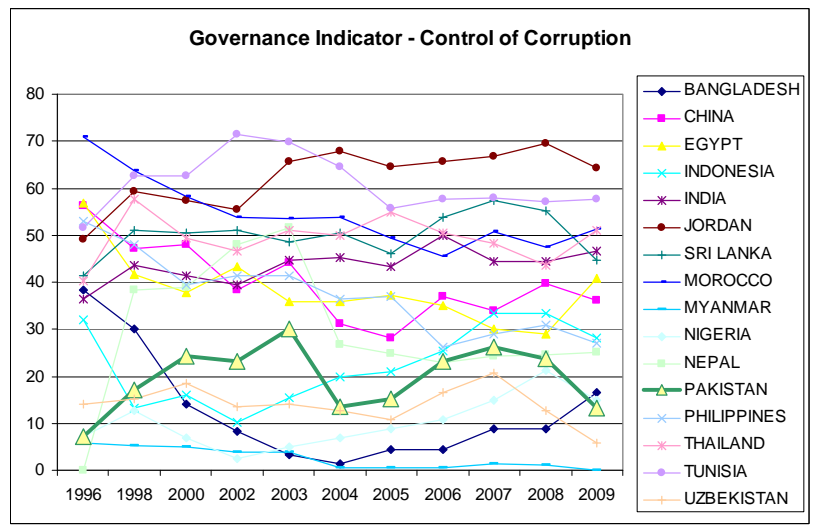

Source: Kaufmann, D., Kraay, A., \& Mastruzzi, M. (2004).

IMF Reports on the Observance of Standards and Codes

The IMF's reports on the observance of standards and codes (ROSCs) evaluate the extent to which countries observe certain internationally recognized standards and codes. The ROSC covers 12 areas and associated standards: accounting, auditing, anti-money laundering and countering the financing of terrorism, banking supervision, corporate governance, data dissemination, fiscal transparency, insolvency and creditors' rights, insurance supervision, monetary and financial policy transparency, payments systems, and securities regulation. The reports are used for the operational work of the IMF and World Bank, including policy discussions with national authorities, and in the private sector (including by rating agencies) for risk assessment. 
The IMF's 2008 ROSC assigns Pakistan an overall rating of "intent declared" for observing standards in the Code of Good Practices on Transparency in Fiscal Policy. The report acknowledges that there has been much progress, but asserts that more work is needed to fully comply with the code. The report notes that the passage of the Fiscal Responsibility and Debt Limitation Law has been key to the improvements thus far attained in both fiscal discipline and transparency. It also acknowledges that the implementation of the Project for Improvement of Financial Reporting and Auditing and adoption of a new accounting model and chart of accounts have been helpful. However, the ROSC points to the need to build capacity for improving transparency and efficiency. Pakistan's status in terms of the four principles of fiscal transparency is as follows:

1. Clarity of roles and responsibilities

[enacted]

2. Open budget processes

3. Public availability of information

[enacted]

4. Independent assurances of integrity

[intent declared] [intent declared]

Compared to other developing countries, Pakistan's rating in terms of compliance with the Code of Good Practices on Transparency in Fiscal Policy appears to be unfavorable (Figure 13). Pakistan's rating on fiscal transparency did not improve over 2005-11, while five other countries improved, and one maintained its rating.

\section{Figure 13: Comparisons of Fiscal Transparency Ratings}

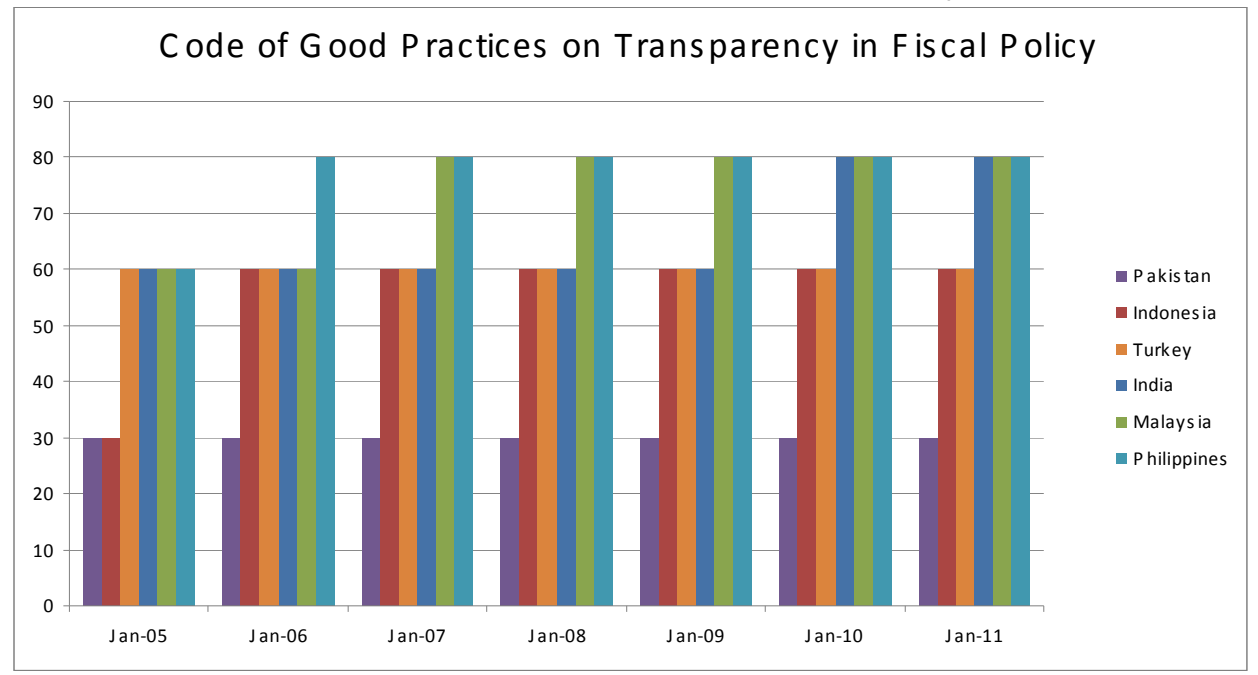

Source: International Monetary Fund. (2008). Pakistan: Report on observance of standards and codes: Fiscal transparency module: An update. 
The Open Budget Index

The Open Budget Index (2010)—a project of the International Budget Partnership-provides another method of assessing fiscal management in 94 countries. The index rating for Pakistan is at 38 percent. The report notes that there is "minimal" openness in the budget process. Figures 14 to 16 compare Pakistan's rating with a group of selected countries. Figure 14 shows that, except for Pakistan, all these countries improved their overall Open Budget Index rating over the three surveys.

Figure 14: Comparisons of Open Budget Index Ratings

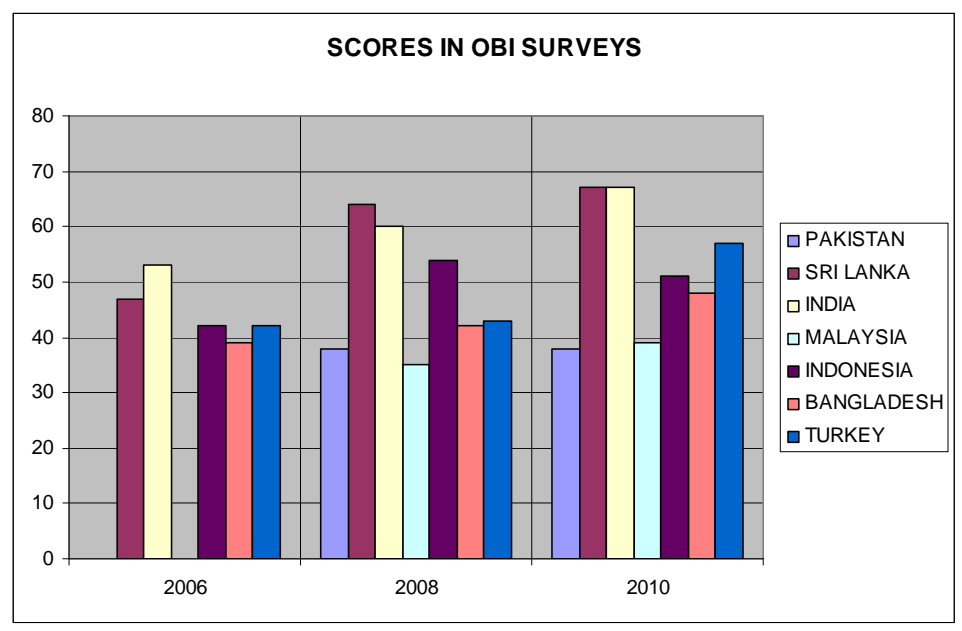

Source: International Monetary Fund. (2008). Pakistan: Report on observance of standards and codes: Fiscal transparency module: An update.

Figure 15 provides a similar picture. Apart from Turkey, all countries improved their ratings in "legislative strength;" Pakistan's rating did not change. Figure 16 indicates that Pakistan's rating in the strength of its supreme audit institution (i.e., the auditor general of Pakistan) actually deteriorated over the three surveys. This is rather surprising given that the department has just implemented the Project for Improvement of Financial Reporting and Auditing bankrolled by the World Bank, and that the IMF's ROSC notes it as being helpful in making the budgetary process more transparent, as noted above. 


\section{Figure 15: Comparisons of Legislative Strength Ratings}

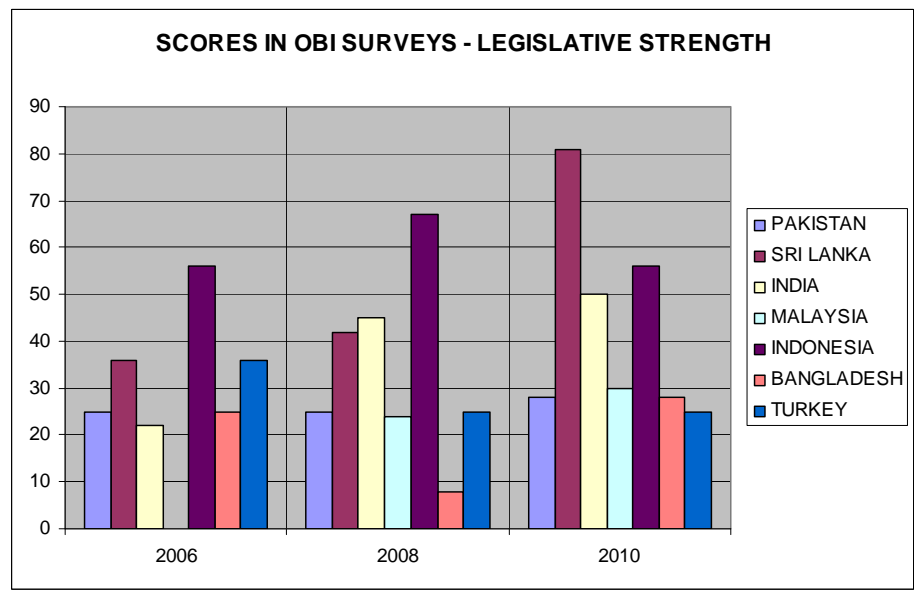

Source: International Monetary Fund. (2008). Pakistan: Report on observance of standards and codes: Fiscal transparency module: An update.

Figure 16: Comparisons of Supreme Audit Institution Ratings

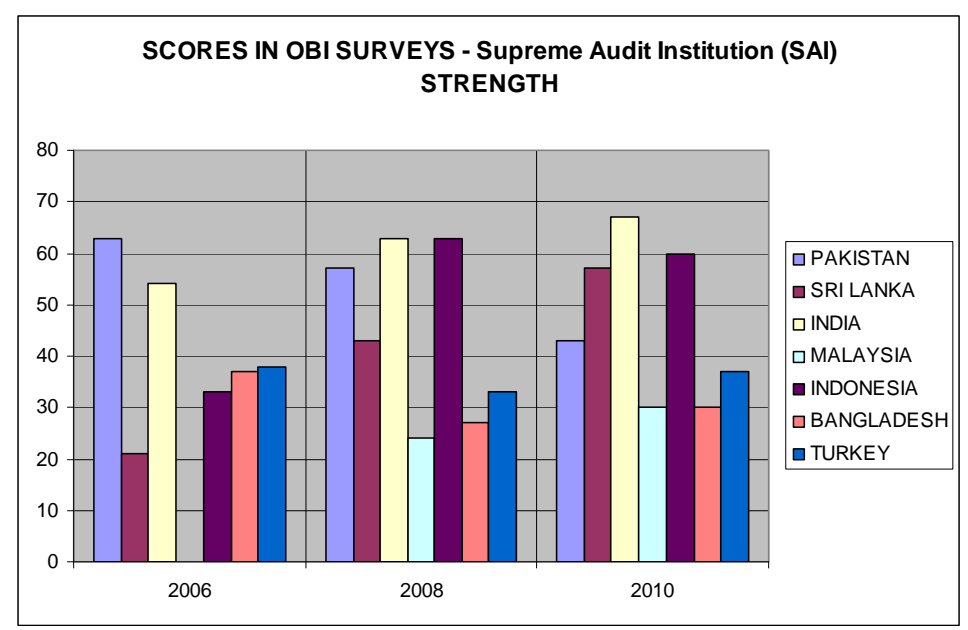

Source: International Monetary Fund. (2008). Pakistan: Report on observance of standards and codes: Fiscal transparency module: An update.

\section{The Bond Market and Fiscal Deficits}

With the rise of financial liberalization and globalization over the last two decades, many emerging economies have had a manifold increase in their bond markets. The public and private sectors have both started to access bond markets to meet their investment and current expenditures. 
Governments prefer to issue bonds in their own markets as an attractive alternative to traditional bank borrowing. Prior to financial liberalization, under regulated financial regimes, governments in developing countries could simply force local banks to hold government paper by enforcing demanding reserve requirements and qualitative controls. Thus, for many countries, government deficits were "inflation financed." The option of foreign borrowing also became restrictive with the liberalization of financial markets; under flexible exchange rate regimes and concomitant free capital flows, governments adopted antiinflationary policies. In this new environment, governments turned increasingly to domestic bond markets to meet their budgetary deficits.

However, the role of bond markets is much broader and of greater consequence than being merely a financing source. Debt markets are critical for a well-balanced financial system in which the government bond market plays a pivotal role. The bond market plays a central role in financial development for the following reasons.

- Debt markets make financial markets more complete, and by determining market interest rates that are commensurate with the opportunity cost of funds for various maturities and levels of risk, they generate market signals for efficient investment and financing decisions and the allocation of financial resources.

- Active bond markets provide liquidity, which reduces the cost of intermediation and makes it possible to hedge maturity risks at lower transaction costs.

- Economies with developed bond markets avoid concentrating intermediation in the banking sector by spreading some corporate risk over their capital markets. Bond markets also offer households and institutions alternatives to bank deposits.

- Bond markets generate important signals for the conduct of macroeconomic policy. Since bond markets react quickly to policy decisions, they generate an immediate signal as to the sustainability of fiscal policies, allowing governments to adjust their policies. When consumer finance and mortgages are linked to bond rates, an increase in bond rates has an immediate political impact that politicians are unlikely to miss. Similarly, bond markets exert a disciplinary influence on monetary policy. Excessive monetary expansion builds up inflation expectations and pushes up long-term rates. Bond yields 
respond quickly to policy decisions, and such "messages" usually have a sobering effect on policymakers.

- An active and liquid debt market facilitates the operation of monetary policy. A well-functioning money market smoothly transmits rate changes throughout the financial system, and has a quick impact on the economy.

\section{Access to Bond Markets: "Original Sin"}

Most countries are unable to borrow abroad in their own currency, and many cannot borrow in local currency at long maturities and fixed rates even at home. This empirical observation was termed "original sin" by Eichengreen and Hausmann (1999). The lack of financial flexibility creates financial fragility as such countries end up with currency mismatches (because of the debt's currency composition) or maturity mismatches (because of the short-term nature of the domestic currency debt), and are characterized by greater output and capital flow volatility, lower credit rating, and limited ability to manage an independent monetary policy (Eichengreen, Hausmann, \& Panizza, 2002).

Hausmann and Panizza (2003) summarize seven theories aimed at explaining the determinants of original sin.

1. Level of development. The state of a country's financial institutions and markets.

2. Monetary credibility. When monetary credibility is low, domestic currency interest rates will be high, driving firms to borrow in hard currencies.

3. Fiscal solvency. Countries with weak public finances have an incentive to debase their currencies. Investors anticipating this withdraw from the long-term debt market, forcing borrowers to dollarize the debt or borrow short-term.

4. Credit market imperfections or poor contract enforcement. A positive correlation between default and depreciation risk creates a moral hazard for the borrower who can expropriate his local currency lenders by taking on more foreign currency debt. Under such circumstances, the domestic currency debt market may disappear.

5. Exchange rate regime. Countries with fixed exchange rate regimes experience volatile domestic currency interest rates, while countries with floating exchange rates experience exchange rate volatility. 
Borrowers are then likely to prefer domestic currency debt in floating rate countries and fixed rate debt in flexible exchange rate countries.

6. Political economy arguments. According to this line of reasoning, when foreigners are the main holders of domestic currency debt, governments will have an incentive to debase their currencies. In this sense, international markets in domestic currency can only arise in the presence of a domestic constituency of local currency debt holders.

7. Role of economies of scale in liquidity. Larger countries' currencies have an advantage in the international market because their economy size and currency issues make them liquid and stable and, hence, attractive as a component of the world portfolio.

Researchers argue that weaknesses in economic policies and underdeveloped financial institutions exacerbate the problem of original sin. Eichengreen and Hausmann (1999) suggest that emerging markets cannot overcome original sin on their own. Eichengreen et al. (2002) support the idea that original sin is exogenous to developing countries that cannot do much about it, such as improving the rule of law or containing inflation. On the other hand, La Porta, López-de-Silanes, Shleifer, \& Vishny (1997) find empirical evidence that a country's legal environment does matter: countries with better rule of law and creditors' rights have larger debt markets (bank debt plus nonfinancial bonds).

Other studies (Eichengreen et al., 2002; Hausmann \& Panizza, 2003) find that domestic financial development-in terms of its size relative to GDP or to the presence of foreign lenders-is not robustly correlated with the measure of original sin. Hausmann and Panizza (2003) find a relatively low correlation between the ability to borrow internationally in domestic currency and the ability to do so domestically at long maturities and fixed rates (DSIN2). They note that countries such as Chile, Hungary, India, Israel, the Philippines, the Slovak Republic, and Thailand do not exhibit domestic variants of original sin, but do exhibit the international variety. In their study, the only variable that seems robustly related to the international variant of original sin is the absolute size of the economy, which suggests that the international version of original sin is driven by the presence of economies of scale caused by liquidity or other factors.

In explaining the domestic version of original sin, Hausmann and Panizza (2003) find that neither the size of the economy nor measures of the level of development or institutional quality is associated with the 
phenomenon. However, monetary credibility-measured by lower average inflation - the imposition of capital controls, and exchange rate flexibility are associated with a lower level of domestic original sin. Exchange rate flexibility is also negatively correlated with domestic original sin but once capital controls are taken into account, there is no additional explanatory power to the exchange rate regime. They interpret this to mean that, while capital controls may be good for reducing domestic original sin, they may exacerbate international original sin.

The implications of whether original $\sin$ is exogenous or endogenous are important. If original sin is exogenous, relief from it can be sought at the level of international organizations. If original sin is endogenous, then the local legal environment and governance should be improved. There is, nevertheless, empirical evidence that "policies aimed at widening the investor base are instrumental to reduce domestic debt riskiness and tilt its composition towards safer, long-term, unindexed, local currency instruments" (Arnaud \& Reynaud, 2005).

Market Discipline and the Role of Bond Vigilantes

The extant research finds evidence that financial markets react significantly to changes in the structure or levels of public debt. Evidence on the reaction of fiscal policy to financial market indicators is unclear. However, researchers find that countries reduce their primary deficits as a reaction to high debt servicing costs. Many scholars have examined the magnitude of the impact of fiscal deficits and public debt on long-term interest rates, and the extent to which it is influenced by other factors such as the private savings rate, demographics, the quality of institutions, and international financial integration.

In the neoclassical model, large fiscal deficits create an excess supply of government debt, leading to higher real interest rates. The yield curve also becomes positively sloped in anticipation of continuing large fiscal deficits. If combined with increased economic uncertainty, fiscal deficits could also raise concerns about the government's ability to service its debts and raise credit risk premiums. Higher inflation expectations and concerns about the monetization of debt increase the inflation premiums embodied in the nominal rates. Some factors may weaken the link between fiscal deficits and interest rates. For instance, capital inflows may complement domestic savings in an open economy for some time by leading to real exchange rate appreciation rather than higher real interest rates. For many reasons, the results of many studies remain mixed. Gale 
and Orszag (2002) survey almost 60 studies and find in around half of them a "predominantly positive significant" effect of fiscal deficits on interest rates, and in the other half a "mixed" or "predominantly insignificant" effect.

A recent study by Baldacci and Kumar (2010) assesses empirically the impact of fiscal deficits and public debt on long-term interest rates over almost three decades, taking into account a wide range of countryspecific factors, for a panel of 31 advanced and emerging market economies. Their key finding is that "the impact of fiscal deterioration on long-term interest rates is significant and robust but nonlinear. Moreover, the magnitude of the impact reflects initial fiscal, institutional and structural conditions, as well as spillovers from global financial markets." Baldacci and Kumar note in particular that "differences in institutional features and domestic private saving rates also play a role in determining the impact of deficits on interest rates. The quality of governance is important, as better institutions signal the credibility of economic policies, thereby reducing risks about policy implementation."

The market discipline hypothesis would suggest, first, that the debt market responds to fiscal deficits by increasing the default risk premium of sovereign governments. Second, sovereign borrowers respond in turn to the increased yields by making fiscal adjustments. Bulut (2009) considers the two aspects of the market discipline hypothesis simultaneously by employing 3SLS to incorporate the contemporaneous feedback effects between primary structural budget balances and country default risk premiums. His results show that financial markets have a disciplinary effect on sovereign governments, and that the latter are more disciplined in countries with floating exchange rate regimes, while countries with fixed exchange rate regimes seem to be irresponsive to the change in the default risk premium posed by the market. Overall, markets seem to respond to changes in fiscal indicators as expected of well-functioning financial markets.

Spiegel (2008) notes that "the literature appears to have reached a consensus that financial globalization has had a 'disciplining effect' on monetary policy, as it has reduced the returns from and hence the temptation for using monetary policy to stabilize output." Cuadra, Sanchez, \& Sapriza (2009) explain the pro-cyclicity of fiscal policies in emerging market in terms of their ability to access to foreign debt and the possibility of sovereign default and associated risk premium. Akitoby and Stratmann (2006) find that reductions in public expenditure are a 
more powerful tool for reducing spreads than increases in revenues. They also show that debt-financed current spending increases sovereign risk by more than tax-financed current spending.

\section{Evidence from Pakistan}

There has been limited research on the impact of fiscal policy on the linkages between fiscal deficits and financial markets in Pakistan. Hakro (2009) demonstrates that the causality link of deficits flows from budget deficits to prices to interest rates to capital flows to exchange rates and to trade deficits. He suggests that reductions in budget deficits might help control the level of prices. An empirical analysis by Agha and Khan (2006) suggests that inflation in Pakistan is not only related to fiscal imbalances but also to the sources of financing fiscal deficit and, therefore, the fiscal sector is dominant in explaining price movements.

\section{Developing Bond Markets}

In Pakistan, and similar to many Asian economies, the banking system has tended to dominate the economy while capital markets have been relatively slow to develop. Also, in Pakistan, as in many other countries, the bond market is dominated by government bonds. There are several reasons that explain this pattern: (i) a greater preference for liquid short-term bank deposits, (ii) underdeveloped or nonexistent institutional investors, (iii) few companies that are sufficiently large and reputable to issue bonds, and (iv) the absence of the requisite informational, legal, and judicial infrastructure.

Despite conscious plans to foster the growth of the bond market in Pakistan, the country's experience does not compare favorably with many other developing countries. Figure 17 depicts the size of the total bond market as a percentage of GDP for a selected group of countries. These are domestic bonds, which include government bonds, and bonds issued by financial institutions and corporate issuers. 
Figure 17: Selected Countries' Domestic Debt, 1999-2009

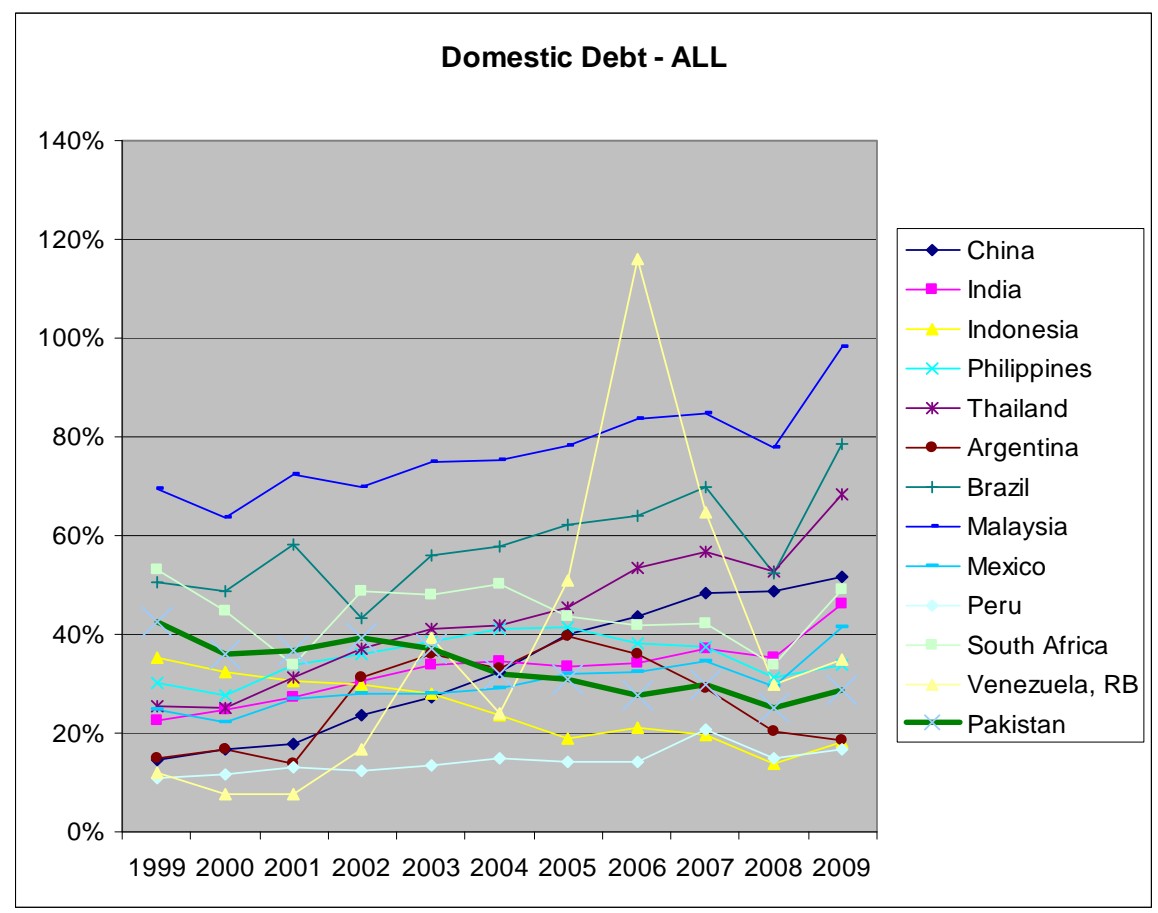

Source: State Bank of Pakistan, 2010.

As the figure shows, Pakistan's bond market has followed a negative trend over the last 20 years in contrast to other countries in the group, which have exhibited a steady upward trend. To draw a poignant comparison, we show in Figure 18 a comparison with India. The positive trend followed by the Indian bond market stands in sharp contrast to the market in Pakistan. As the Indian bond market has grown over time, it has also assumed greater depth. This is indicated by the growth in bonds issued by financial institutions and domestic corporations (Figure 19). 


\section{Figure 18: Domestic Debt Securities}

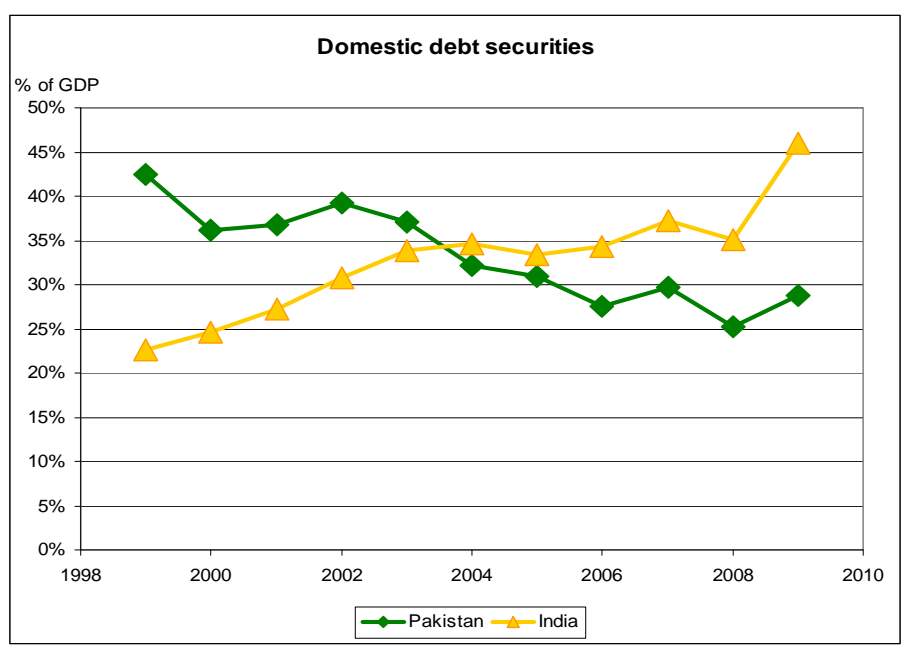

GDP = gross domestic product.

Source: State Bank of Pakistan, 2010.

Figure 19: Domestic Debt Securities as a Percentage of GDP

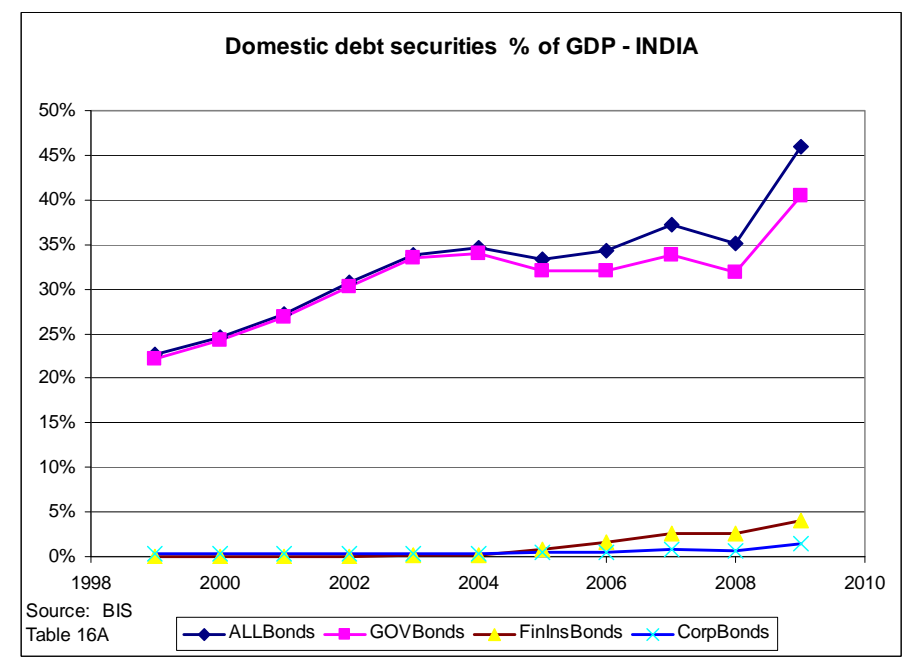

GDP $=$ gross domestic product.

Source: State Bank of Pakistan, 2010. 
Impediments to the development of domestic debt markets, particularly the corporate bond market, have been discussed in various papers and reports (see, for example, Arif, 2007; Hameed, 2007; State Bank of Pakistan, 2006, 2010). The typical reasons given include: (i) relatively higher yields available on national saving scheme instruments, (ii) the heavy burden of and aversion to disclosure requirements, (iii) high transaction costs, and (iv) an illiquid secondary market. However, the key to developing a vibrant and functionally efficient bond market may lie in the development of a conducive regulatory and institutional environment.

A study by Burger and Warnock (2006) concludes that policies and laws matter in the development of local currency bond markets and can alleviate the burden of original sin. By improving policy performance and strengthening institutions, developing countries can develop bond markets, reduce their currency mismatch, and reduce the likelihood of future crises. Their analysis indicates that both creditor-friendly policies and creditor-friendly laws can play an effective role in bond market development. The empirical evidence shows that countries with better historical inflation performance have more highly developed local bond markets, both private and government, and rely less on foreign currencydenominated bonds. Laws that are "creditor-friendly" make a difference. They point out that the "strong rule of law is associated with deeper local bond markets, whereas countries with better creditor rights are able to issue a higher share of bonds in their local currency." They also show that the conditions necessary for bond market development are very similar to those that foster the development of the banking system. Therefore, it may not be necessary to make a policy choice between developing a bank- or debt market-based financial system.

Uppal (2007) provides evidence that securities laws play an important role in the development of bond markets because they facilitate private contracting rather than public enforcement. The study empirically investigates the features and enforcement of securities laws that may facilitate or constrain the broadening and deepening of the corporate bond market. The study examines bond market development in 49 countries, using corporate governance and securities law indices developed by La Porta, López-de-Silanes, \& Shleifer (2006), which include disclosure requirements, liability standards, public and private enforcement, anti-director rights, and the effectiveness of the judiciary. Employing a Tobit estimation procedure to deal with the econometric issues associated with truncated data, the study shows that securities laws play an important role in the development of bond markets just as 
they do in the case of stock markets. The study's results further support the argument that securities laws matter because they facilitate private contracting rather than public regulatory enforcement. Contrary to the La Porta et al. (2006) findings with respect to stock market developmentthat several aspects of public enforcement do not matter-Uppal's results indicate that the supervisor's power to impose criminal sanctions may have a bearing on bond market development.

Fostering the development of bond markets remains a challenge for many developing countries. Turner (2003) offers a number of strategies to develop bond markets, noting that many countries have been successful in developing their own bond markets in terms of market size: "Yet in terms of liquidity the results have been somewhat disappointing." While it might be difficult for a country with a small investor base and few market traders to develop a competitive bond market, the fact that many countries-irrespective of their size-have liquid bond markets suggests that most medium-sized emerging market countries can develop liquid bond markets. However, in order to achieve this goal, policymakers need to examine the totality of governance and institutional environments that might impede the development of bond markets.

\section{Conclusion}

Instilling fiscal discipline is a multidimensional challenge. Despite the conclusions of economic models exhorting fiscal prudence, the problem will remain intractable unless approached comprehensively and in its entirety. Long-term solutions must be found in the development of political institutions, improved governance, and institutions that are conducive to fiscal discipline. There is abundant of analysis and advice, and there seems to be a consensus on what will likely work. The real challenge may lie in summoning the political will, public awareness, and political energy to implement the required measures.

An active and liquid bond market can play a crucial role in bringing about fiscal discipline. The advocacy for instituting fiscal policy discipline based on rules has been building up following the adoption of rule-based monetary policies by many countries. Wyplosz (2002) points to the notion that fiscal policy is a purely political function that must remain fully subject to the usual process of parliamentary oversight. However, he argues that the fiscal deficit should be a macroeconomic choice. On other hand, the budget structure (size, allocation of 
expenditures, and taxes) legitimately falls in the political domain. He concludes that "budget deficits, like interest rates, are best left to nonpolitical bodies which operate in full light and are subject to democratic accountability." Bond markets can be instrumental in rationalizing the policy toward budgetary deficits. 


\section{References}

Agha, A. I., \& Khan, M. S. (2006). An empirical analysis of fiscal imbalances and inflation in Pakistan. State Bank of Pakistan Research Bulletin, 2(2), 343-362.

Akitoby, B., \& Stratmann, T. (2006). Fiscal policy and financial markets (Working Paper No. 06/16). Washington, DC: International Monetary Fund.

Alesina, A., \& Perotti, R. (1994). The political economy of budget deficits (Working Paper No. 4637). Cambridge, MA: National Bureau of Economic Research.

Alesina, A., \& Perotti, R. (1995). The political economy of budget deficits. International Monetary Fund Staff Papers, 42(1), 1-31.

Alesina, A., \& Perotti, R. (1999). Budget deficits and budget institutions. In J. M. Poterba \& J. von Hagen (Eds.), Fiscal institutions and fiscal performance. Chicago, IL: University of Chicago Press.

Alesina, A., \& Tabellini, G. (1990). Voting on the budget deficit. American Economic Review, 80(1), 37-49.

Alesina, A., \& Tabellini, G. (2005). Why is fiscal policy often procyclical? (Working Paper No. 11600). Cambridge, MA: National Bureau of Economic Research.

Alt, J., \& Lassen, D. (2006). Fiscal transparency, political parties, and debt in OECD countries. European Economic Review, 50(6), 1403-1439.

Arif, M. (2007). Developing bond market in Pakistan. State Bank of Pakistan Research Bulletin, 3(1), 129-157.

Baldacci, E., \& Kumar, M. S. (2010). Fiscal deficits, public debt, and sovereign bond yields (Working Paper No. 10/184). Washington, DC: International Monetary Fund.

Barro, R. (1979). On the determination of the public debt. Journal of Political Economy, 87, 940-947. 
Brender, A., \& Drazen, A. (2005a). Political budget cycles in new versus established democracies. Journal of Monetary Economics, 52(7), 1271-1295.

Brender, A., \& Drazen, A. (2005b). How do budget deficits and economic performance affect reelection prospects? Evidence from a large crosssection of countries (Working Paper No. 11862). Cambridge, MA: National Bureau of Economic Research.

Bulut, L. (2011). Market disciplining of the developing countries' sovereign governments [Electronic version]. Contemporary Economic Policy, 29. doi: 10.1111/j.1465-7287.2011.00253.x

Burger, J. D., \& Warnock, F. E. (2006). Local currency bond markets. International Monetary Fund Staff Papers, 53(Special Issue), 133-146.

Cuadra, G., Sanchez, J. M., \& Sapriza, H. (2009). Fiscal policy and default risk in emerging markets (Working Paper No. 09-01). Richmond, VA: Federal Reserve Bank of Richmond.

Drazen, A. (2000). Political economy in macroeconomics. Princeton, NJ: Princeton University Press.

Eichengreen, B., Hausmann, R., \& Panizza, U. (2002, November). Original sin: The pain, the mystery, and the road to redemption. In Currency and maturity matchmaking: Redeeming debt from original sin. Conference conducted by the Inter-American Development Bank, Washington, DC.

Eslava, M. (2006). The political economy of fiscal policy: Survey (Working Paper No. 583). Washington, DC: Inter-American Development Bank.

Hakro, A. N. (2009). Twin deficits causality link: Evidence from Pakistan. International Research Journal of Finance and Economics, 24, 54-74.

Hameed, F. (2007). Fostering the corporate bond market in Pakistan. State Bank of Pakistan Research Bulletin, 3(1), 107-128.

Hausmann, R., \& Panizza, U. (2003). The mystery of original sin. Cambridge, MA: Harvard University Press. 
Huther, J., \& Shah, A. (1998). Applying a simple measure of good governance to the debate on fiscal decentralization. Paper presented at a seminar conducted by the US Agency for International Development, Venezuela.

Inter-American Development Bank. (2005). Unlocking credit: The quest for deep and stable bank lending. Washington, DC: Author.

International Monetary Fund. (2008). Pakistan: Report on observance of standards and codes: Fiscal transparency module: An update (Country Report No. 08/129). Washington, DC: Author. Retrieved from http:/ / www.imf.org/external/pubs/ft/scr/2008/cr08129.pdf

Kaufmann, D., Kraay, A., \& Mastruzzi, M. (2004). Governance matters III: Governance indicators for 1996, 1998, 2000, and 2002. World Bank Economic Review, 18, 253-287.

La Porta, R., López-de-Silanes, F., \& Shleifer, A. (2006). What works in securities laws? Journal of Finance, 61(1), 1-32.

La Porta, R., López-de-Silanes, F., Shleifer, A., \& Vishny, R. (1997). Legal determinants of external finance. Journal of Finance, 52, 1131-1150.

Martinez-Vazquez, J., Arze, F. J., \& Boex, J. (2006). Corruption, fiscal policy, and fiscal management: Fiscal reform in support of trade liberalization. Atlanta: Georgia State University.

Mehl, A., \& Reynaud, J. (2005). The determinants of domestic original sin in emerging market economies (Working Paper No. 560). Frankfurt, Germany: European Central Bank.

Open Budget Initiative. (2010). Open budget index 2010: Pakistan. Retrieved from http://www.openbudgetindex.org/CountrySummaryPakistan.pdf

Poterba, J. M. (1995). Balanced budget rules and fiscal policy: Evidence from the States. National Tax Journal, 48(3), 329-336.

Rogoff, K. (1990). Equilibrium political budget cycles. American Economic Review, 80, 21-36.

Rogoff, K., \& Sibert, A. (1988). Elections and macroeconomic policy cycles. Review of Economic Studies, 55, 1-16. 
Schaeffer, M. (2002). Corruption and public finance. In Sectoral perspectives on corruption. Washington, DC: Management Systems International and USAID.

Schuknecht, L. (1994). Political business cycles and expenditure policies in developing countries (Working Paper No. 121). Washington, DC: International Monetary Fund.

Shi, M., \& Svensson, J. (2006). Political budget cycles: Do they differ across countries and why? Journal of Public Economics, 90 (September), 1367-1389.

Somogyi, F. (2006). Do financial markets really discipline governments? Zurich, Switzerland: Swiss Federal Institute of Technology.

Spiegel, M. (2008). Financial globalization and monetary policy discipline: A survey with new evidence from financial remoteness. San Francisco, CA: Federal Reserve Bank of San Francisco.

State Bank of Pakistan. (2006). Financial Stability Review, 2005-06. Karachi, Pakistan: Author.

State Bank of Pakistan. (2010). Government borrowing from the banking system: Implications for monetary and financial stability. Financial Stability Review, 2009-10. Karachi, Pakistan.

State Bank of Pakistan. (2010). Role of government in facilitating development of the bond market. Financial Stability Review, 200910. Karachi, Pakistan.

Stein, E., Talvi, E., \& Grisanti, A. (1998). Institutional arrangements and fiscal performance: The Latin American experience (Working Paper No. 6358). Cambridge, MA: National Bureau of Economic Research.

Tanzi, V. (1999). Governance, corruption, and public finance: An overview. In S. Schiavo-Campo (Ed.), Governance, corruption, and public financial management. Manila, Philippines: Asian Development Bank.

Turner, P. (2003). Bond market development: What are the policy issues? In The future of domestic capital markets in developing countries. Conference conducted by the World Bank, International Monetary Fund, and Brookings Institution, Washington, DC. 
Uppal, J. Y. (2007). Role of securities law in the development of domestic corporate bond markets. State Bank of Pakistan Research Bulletin, 3(1), 75-88.

Von Hagen, J. (1992). Budgeting procedures and fiscal performance in the European Community (Economic Paper No. 96). Brussels, Belgium: European Commission.

Weingast, B., Shepsle, K., \& Johnsen, C. (1981). The political economy of benefits and costs: A neoclassical approach to distributive politics. Journal of Political Economy, 89, 642-664.

World Bank. (2005). Country policy and institutional assessments: Assessment questionnaire. In Operations policy and country services. Washington, DC: Author.

Wyplosz, C. (2002). Fiscal discipline in emerging market countries: How to go about it. Geneva, Switzerland: Graduate Institute for International Studies and Centre for Economic Policy Research. 